\title{
Early screening of reading and writing difficulties in the first grade - a pilot study
}

\author{
Angela von Fritsch ${ }^{1}$ \\ https://orcid.org/0000-0001-8443-3281 \\ Nathane Sanches Marques Silva ${ }^{2}$ \\ https://orcid.org/0000-0001-6047-2534 \\ Maura Ligia Sanchez $z^{3}$ \\ https://orcid.org/0000-0003-0713-985X
}

Instituto Leia Bem, São Paulo, São Paulo, Brasil.

Universidade Federal de São Paulo UNIFESP, São Paulo, São Paulo, Brasil.

CEFAC - Consultoria em Fonoaudiologia Clínica, São Paulo, São Paulo, Brasil.

Conflict of interests: Nonexistent

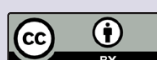

Received on: August 5, 2020

Accepted on: January 21, 2021

Corresponding address:

Angela von Fritsch

Rua Barão do Triunfo, 612, Conjunto 809

CEP: 04602-002 - Brooklin - São Paulo,

São Paulo, Brasil

E-mail: angelafono@institutoleiabem.com.br

\section{ABSTRACT}

Purpose: to investigate the effectiveness of an early identification screening based on the Dynamic Indicators of Basic Early Literacy Skills (DIBELS) test, $6^{\text {th }}$ edition, to early identify first graders at risk of dyslexia.

Methods: the sample comprised 34 children assessed at two moments - the screening was conducted while they were in the first grade, while a word dictation was used when they were in the second grade. The data were analyzed with Pearson's correlation test, linear regression analysis, and ANOVA, with a p-value $\leq 0.05$.

Results: the results provide evidence that agrees with other studies in that children with signs of risk of dyslexia differ from children with typical development in terms of less phonological skills and that these differences are already present at the beginning of the literacy process.

Conclusion: the early screening allows for the identification of the risk factors for dyslexia, making it possible to implement preventive and personalized phonological skills training to make the literacy process easier.

Keywords: Dyslexia; Reading; Handwriting; Academic Failure 


\section{INTRODUCTION}

People with dyslexia have difficulty learning to read, which interferes with their social, educational, and professional development. This neurological hereditary disorder affects from $5 \%$ to $20 \%$ of the world population ${ }^{1}$, depending on the criteria used.

A typical reader can quickly understand the relationship between letters and sounds, connect and manipulate them to form words, quickly progressing to fluent reading with comprehension, while people with dyslexia have difficulty acquiring this skill and may not become fully literate ${ }^{2}$.

Early identification instruments and strategies used at school can and should identify the children that are not achieving the expected academic performance in the first grade ${ }^{3}$. Thus, it is not necessary to wait for the children's failures for them to meet the diagnosis criteria and start the intervention. Many children will respond to early intervention; hence, longer diagnosis processes will only be necessary for those who respond to it unsatisfactorily ${ }^{4}$.

Early intervention can mitigate the child's risk of developing severe reading difficulties ${ }^{4}$ that would make them sharply anxious with the recurrent feeling they will make mistakes or fail ${ }^{5}$.

The neurological basis of dyslexia makes it a persistent reading and writing disorder. Some studies suggest that there is a functional deficit in the brain organization that underlies dyslexia which may be reverted if the child is submitted to an intensive intervention beginning as soon as possible ${ }^{6}$.

An analysis comparing early intervention studies demonstrated that the intervention carried out in preschool and first grade was more effective than when conducted in second or third grade. Preventing reading and writing failure has effects on the child, their family, and the society at large. Fewer children with dyslexia graduate from universities and they are more likely to enter the juvenile penal system. Not having to go so far, the early identification of reading and writing difficulties can make a huge difference in the child's and their family's well-being?.

In clinical practice, it is observed that children are first referred for interventions due to academic difficulties when they are in third grade, sometimes even in fourth grade, when they already present difficulties secondary to the slow identification of letters, such as problems decoding the graphic code, poor reading fluency, and difficulty understanding written statements ${ }^{8}$.
The primary purpose of early screening is to identify children at risk for them to receive appropriate instructions and interventions to enable them to read as soon as possible ${ }^{4}$.

Hence, there is an unending search for a reliable screening easy to apply in the school setting. In this sense, DIBELS ${ }^{9}$ - Dynamic Indicators of Basic Early Literacy Skills - a test created between 1970 in 1980 in the Institute for Research and Learning Disabilities at the University of Minnesota, is a set of procedures and measures to assess the acquisition of skills underlying the acquisition of reading from preschool to the eighth grade. It aims to test phonemic awareness, the alphabetic principle, and accuracy (precision) in the identification of letters in the first grade. As it separately assesses these three areas, it is possible to quickly detect the impaired one. DIBELS is a screening that meets the requirements of being fast, applicable to the whole class to identify risks, and economically feasible to schools, as the teachers themselves can apply it after being properly trained.

This study aimed to investigate the effectiveness of an early screening based on DIBELS 6th Edition ${ }^{9}$ to identify children at risk of difficulties acquiring reading and writing.

\section{METHODS}

This study was approved by the Research Ethics Committee of the Center for Specialization in SpeechLanguage-Hearing Sciences (Centro de Especialização em Fonoaudiologia Clínica - CEFAC), Brazil, under evaluation report no. $3.489 .875 / 2019$. The participants assessed were only those who turned in the informed consent form signed by their parents or guardians.

This is a pilot study of a cross-sectional one in which 34 children participated, aged 6 and 7 years $(M=6.5$; $\mathrm{SD}=0.5$ ), of whom $64.7 \%$ were females, enrolled in the first grade of a private elementary school in the city of São Paulo.

As inclusion criteria, the children had to be enrolled in the school selected for the research; speak Portuguese as their native language; not be diagnosed with intellectual disability, autism spectrum disorder, and/or hearing loss registered in their school record.

This study considered as signs of risk of dyslexia the difficulties in the phonemic awareness and letter identification phonological skills in comparison with same-age children who received the same stimulation, as they belonged to the same school group. 
Data were collected in two stages. Firstly, the early identification screening instrument was applied in November, in the second term of first grade in elementary school, the time when the teachers at the participating school considered it ideal, as they had already introduced most of the letters to the students. After 7 months, the researchers returned to the school to apply a dictation to monitor their progress in the writing acquisition process.

To apply the early identification screening, two examiners - speech-language-hearing therapists - went to the school and conducted the procedure individually with each first-grade child during school hours. The application took place in a quiet room, away from distractions. All the screening tests were timed, which was marked in individual answer sheets.

The early identification screening was developed based on DIBELS 6th ${ }^{9}$ and is divided into five tests that assess early reading and writing skills (full screening in DIBELS 6th Edition ${ }^{9}$.
The first test, the Letter Naming Fluency test (LNF), consists of counting how many letters, out of a board with 110 letters, the child can correctly name in one minute. In the second test, the Initial Sound Fluency (ISF), the child is asked to identify which of the four presented images begins with the sound produced by the examiner. The Phoneme Segmentation Fluency test (PSF) assesses the child's ability to fluently segment three- or four-phoneme words. The Nonsense Words Fluency test (NWF) assesses the alphabetic principle, requiring the child to produce the sounds of the letters or read the pseudowords presented. The last test, Word Use Fluency (WUF), assesses the capacity to form oral statements based on a word given by the examiner.

The children's score was computed with the mean correct answers in the first minute performing each task. The tasks were interrupted following the test's discontinuity rules, fully described in detail in DIBELS 6th Edition ${ }^{9}$. Chart 1 presents in percentage what is expected for the age group analyzed in each task in the original English test ${ }^{9}$.

Chart 1. Means to analyze the early identification screening tests

\begin{tabular}{|c|c|}
\hline 1. Letter Naming Fluency (LNF) & $\begin{array}{l}\text { - Risk of difficulties in reading and writing acquisition: A score in the lower } 20 \% \text { in relation to } \\
\text { the performance of the class. } \\
\text { - Some risk of reading and writing acquisition: A score between } 20 \text { and } 40 \% \text { in relation to the } \\
\text { performance of the class. } \\
\text { - Low risk of difficulties in reading and writing acquisition: A score above } 40 \% \text { in relation to the } \\
\text { performance of the class. }\end{array}$ \\
\hline 2. Initial Sound Fluency (ISF) & $\begin{array}{l}\text { Appropriate to monitor the progress of children with phonological awareness difficulties, but there } \\
\text { are no reference values. }\end{array}$ \\
\hline $\begin{array}{l}\text { 3. Phoneme Segmentation Fluency } \\
\text { (PSF) }\end{array}$ & $\begin{array}{l}\text { The expected in this task is } 71 \text { letter sounds per minute }(50 \%) \text { by the end of the first grade. Students } \\
\text { whose score is lower than } 62(40 \%) \text { by the end of first grade may need intensive instruction to } \\
\text { reach the reading and writing goals. }\end{array}$ \\
\hline $\begin{array}{l}\text { 4. Nonsense Words Fluency } \\
\text { (NWF) }\end{array}$ & $\begin{array}{l}\text { The goal is to correctly name per minute } 50 \% \text { of the sounds by the end of the first grade. Students } \\
\text { whose score is lower than } 40 \% \text { by the end of the first grade may need intensive instruction to } \\
\text { reach the reading goals. }\end{array}$ \\
\hline 5. Word Use Fluency ( & $\begin{array}{l}\text { Children with a percentage lower than } 20 \% \text {, when compared with the same group, must be } \\
\text { considered at risk of poor results in language and reading. And those with a percentage between } \\
20 \% \text { and } 40 \% \text { must be considered at some risk. }\end{array}$ \\
\hline
\end{tabular}

Seven months after applying the early identification screening, a dictation was applied by each class' own teacher to monitor the acquisition of the alphabetic principle and the phoneme-grapheme relationship, and to compare it with the performance in the phonological tasks applied in the first testing. The dictation was developed by the authors, who tried to present the least disyllabic words encompassing all the syllables and all the letters. The result was a dictation with 15 disyllabic words. It was decided to use disyllabic words because in longer ones the phonological working memory - which can be impaired in neurodevelopmental disorders such as dyslexia - could be recruited more often ${ }^{11}$. It was not the objective of this study to assess the children's 
phonological working memory, but the acquisition of the alphabetic principle. Thus, with disyllabic words, the phonological working memory interfered less with the children's performance.

The word dictation was chosen to monitor them after 7 months to allow the teachers to perform it and because it was easier to be applied at the school setting than presenting recordings of excerpts read by the students; thus, the process was more feasible for the schools. Also, in word dictation tests, people with dyslexia present greater loss than schoolchildren without the disorder, and the dictation allows for the analysis of the types of mistakes made. Hence, the number of mistakes made was used to measure the children's performance in decoding words.

\section{Data analysis}

Descriptive analyses were conducted for the screening tests, obtaining the mean values, standard deviation, percentage, and confidence interval for the mean. Pearson's correlation and the linear regression analysis were used to correlate the screening score results with the mistakes in the dictation. The ANOVA test was applied to compare the groups. The values were considered statistically significant when $p \leq 0.05$. The SPSS version 20 and Excel Office 2010 were the software used.

\section{RESULTS}

The sample comprised 34 children assessed at two moments - the screening conducted while they were in the first grade and the word dictation when they were in the second grade.

The children were divided into three performance groups according to their score in the screening tests $(0-20 \%, 20-40 \%$, and more than $40 \%$ of correct answers). To this end, the children's correct answer mean percentage analysis was used (Table 1).

Table 1. Distribution of the performance in the early identification screening with mean, standard deviation, and percentage

\begin{tabular}{cccccc}
\hline & LNF & ISF & PSF & NWF & WUF \\
\hline Mean & 38.06 & 21.16 & 29.81 & 51.03 & 39.31 \\
SD & 18.19 & 11.21 & 20.98 & 34.63 & 16.90 \\
5th P & 7.55 & 6.4 & 8.65 & 8.05 & 11.3 \\
10th P & 11.6 & 8.007 & 10.2 & 14.1 & 16.4 \\
20th P & 23.6 & 11.302 & 14 & 19 & 26 \\
25th P & 26.75 & 12.7675 & 14 & 29.25 & 27.5 \\
40th P & 33.8 & 16.112 & 17.4 & 36.4 & 35.8 \\
50th P & 38.5 & 20.71 & 22 & 43.5 & 40 \\
75th P & 48.75 & 30.125 & 39.75 & 66 & 53.25 \\
80th P & 56.6 & 31.046 & 48 & 78.4 & 54 \\
90th P & 63.5 & 36.27 & 57.4 & 103.9 & 60 \\
95th P & 64.9 & 38.317 & 70.25 & 115.35 & 63.8 \\
\hline
\end{tabular}

Captions: LNF: letter naming fluency; ISF: Initial Sound Fluency; PSF: Phoneme Segmentation Fluency; NWF: Nonsense Words Fluency; WUF: Word Use Fluency; SD: standard deviation.

The complete descriptive analysis of the early identification screening is shown in Table 2. Based on this analysis and according to their performance in the early identification screening, the children were divided into groups, namely: from 0 to $20 \%, 20$ to $40 \%$, and more than $40 \%$ of correct answers. 
Table 2. Complete descriptive table of the tasks of the early identification screening by the weighted value

\begin{tabular}{|c|c|c|c|c|c|c|c|c|c|c|}
\hline \multicolumn{2}{|c|}{ Groups by performance } & \multirow{2}{*}{$\begin{array}{l}\text { Mean } \\
32.7 \%\end{array}$} & \multirow{2}{*}{$\begin{array}{c}\text { Median } \\
41.4 \%\end{array}$} & \multirow{2}{*}{$\begin{array}{c}\begin{array}{c}\text { Standard } \\
\text { deviation }\end{array} \\
17.3 \% \\
\end{array}$} & \multirow{2}{*}{$\frac{\mathbf{Q 1}}{22.1 \%}$} & \multirow{2}{*}{$\begin{array}{c}\text { Q3 } \\
43.6 \%\end{array}$} & \multirow{2}{*}{$\begin{array}{c}\text { Min } \\
5.7 \%\end{array}$} & \multirow{2}{*}{$\frac{\text { Max }}{50.0 \%}$} & \multirow{2}{*}{$\frac{N}{7}$} & \multirow{2}{*}{$\frac{\text { CI }}{12.8 \%}$} \\
\hline & $0-20 \%$ & & & & & & & & & \\
\hline \multirow[t]{3}{*}{ LNF } & $20-40 \%$ & $36.9 \%$ & $37.1 \%$ & $23.0 \%$ & $20.0 \%$ & $49.3 \%$ & $10.0 \%$ & $72.9 \%$ & 7 & $17.0 \%$ \\
\hline & Above $40 \%$ & $65.0 \%$ & $63.6 \%$ & $22.0 \%$ & $49.6 \%$ & $84.3 \%$ & $24.3 \%$ & $100.0 \%$ & 20 & $9.6 \%$ \\
\hline & $0-20 \%$ & $36.4 \%$ & $38.1 \%$ & $18.4 \%$ & $22.9 \%$ & $46.2 \%$ & $12.9 \%$ & $65.6 \%$ & 7 & $13.6 \%$ \\
\hline \multirow[t]{3}{*}{ ISF } & $20-40 \%$ & $22.8 \%$ & $26.1 \%$ & $10.5 \%$ & $19.9 \%$ & $30.1 \%$ & $2.0 \%$ & $31.6 \%$ & 7 & $7.7 \%$ \\
\hline & Above $40 \%$ & $55.3 \%$ & $52.6 \%$ & $21.3 \%$ & $44.6 \%$ & $68.6 \%$ & $14.6 \%$ & $100.0 \%$ & 20 & $9.3 \%$ \\
\hline & $0-20 \%$ & $15.1 \%$ & $15.9 \%$ & $5.6 \%$ & $13.1 \%$ & $17.0 \%$ & $5.7 \%$ & $23.9 \%$ & 7 & $4.2 \%$ \\
\hline \multirow[t]{3}{*}{ PSF } & $20-40 \%$ & $20.3 \%$ & $15.9 \%$ & $15.6 \%$ & $13.1 \%$ & $18.8 \%$ & $8.0 \%$ & $54.5 \%$ & 7 & $11.6 \%$ \\
\hline & Above $40 \%$ & $43.9 \%$ & $37.5 \%$ & $23.8 \%$ & $26.7 \%$ & $59.1 \%$ & $13.6 \%$ & $100.0 \%$ & 20 & $10.4 \%$ \\
\hline & $0-20 \%$ & $16.4 \%$ & $19.7 \%$ & $9.2 \%$ & $11.8 \%$ & $22.4 \%$ & $0.0 \%$ & $26.8 \%$ & 7 & $6.8 \%$ \\
\hline \multirow[t]{3}{*}{ NWF } & $20-40 \%$ & $16.1 \%$ & $12.6 \%$ & $9.7 \%$ & $11.4 \%$ & $23.6 \%$ & $1.6 \%$ & $28.3 \%$ & 7 & $7.2 \%$ \\
\hline & Above $40 \%$ & $52.5 \%$ & $45.3 \%$ & $23.9 \%$ & $34.8 \%$ & $67.5 \%$ & $26.0 \%$ & $100.0 \%$ & 20 & $10.5 \%$ \\
\hline & $0-20 \%$ & $32.3 \%$ & $29.0 \%$ & $22.6 \%$ & $15.2 \%$ & $48.6 \%$ & $7.2 \%$ & $62.3 \%$ & 7 & $16.7 \%$ \\
\hline \multirow[t]{2}{*}{ WUF } & $20-40 \%$ & $67.5 \%$ & $68.1 \%$ & $16.5 \%$ & $63.0 \%$ & $76.1 \%$ & $37.7 \%$ & $88.4 \%$ & 7 & $12.2 \%$ \\
\hline & Above $40 \%$ & $62.1 \%$ & $55.8 \%$ & $23.6 \%$ & $46.4 \%$ & $80.4 \%$ & $20.3 \%$ & $100.0 \%$ & 20 & $10.4 \%$ \\
\hline
\end{tabular}

Captions: LNF: letter naming fluency; ISF: Initial Sound Fluency; PSF: Phoneme Segmentation Fluency; NWF: Nonsense Words Fluency; WUF: Word Use Fluency; Q: Quartile; Min: minimum; Max: maximum; N: number; $\mathrm{Cl}$ : confidence interval.

In all the performance groups, the correlation between the variables is negative, which shows that the higher the score in the early identification screening, the fewer mistakes in the dictation. However, there was no statistically significant difference between the performance groups from 0 to $20 \%$ and from 20 to $40 \%$. Only when a single group of children performing from 0 to $40 \%$ was compared with the whole class, the difference in performance had statistical significance.

The performance groups had significant differences between the means of correct answers in all the screening tasks and in the relationship between the
Table 3. Correlation between the scores in the early identification screening and mistakes in the dictation

\begin{tabular}{ccc}
\hline & Corr $(\mathbf{r})$ & P-value \\
\hline $0-20 \%$ & $-56.9 \%$ & 0.182 \\
$20-40 \%$ & $-24.5 \%$ & 0.597 \\
Above 40\% & $-18.0 \%$ & 0.447 \\
\hline Total & $-47.5 \%$ & $0.005^{\star}$ \\
\hline
\end{tabular}

$p<0.05$; Pearson's correlation

screening and the number of mistakes in the dictation, except for the WUF (Table 4). 
Table 4. Comparison of the groups for the different tests applied

\begin{tabular}{cccccccccccc}
\hline \multirow{6}{*}{ LNF } & & Mean & Median & $\begin{array}{c}\text { Standard } \\
\text { deviation }\end{array}$ & Q1 & Q3 & Min & Max & N & CI & P-value \\
& $0-20 \%$ & 22.9 & 29 & 12.1 & 15.5 & 30.5 & 4 & 35 & 7 & 9.0 & \\
& $20-40 \%$ & 25.9 & 26 & 16.1 & 14 & 34.5 & 7 & 51 & 7 & 11.9 & 0.001 \\
& Above 40\% & 45.5 & 44.5 & 15.4 & 34.75 & 59 & 17 & 70 & 20 & 6.7 & \\
WUF & $0-20 \%$ & 22.3 & 20 & 15.6 & 10.5 & 33.5 & 5 & 43 & 7 & 11.5 & \\
& $20-40 \%$ & 46.6 & 47 & 11.4 & 43.5 & 52.5 & 26 & 61 & 7 & 8.4 & 0.008 \\
& Above 40\% & 42.9 & 38.5 & 16.3 & 32 & 55.5 & 14 & 69 & 20 & 7.2 & \\
FPP & $0-20 \%$ & 20.9 & 25 & 11.7 & 15 & 28.5 & 0 & 34 & 7 & 8.7 & \\
& $20-40 \%$ & 20.4 & 16 & 12.3 & 14.5 & 30 & 2 & 36 & 7 & 9.1 & $<0.001$ \\
& Above 40\% & 66.7 & 57.5 & 30.3 & 44.25 & 85.75 & 33 & 127 & 20 & 13.3 & \\
\multirow{5}{*}{ ISF } & $0-20 \%$ & 16.8 & 17.6 & 8.5 & 10.6 & 21.4 & 6.0 & 30.4 & 7 & 6.3 & \\
& $20-40 \%$ & 10.6 & 12.1 & 4.8 & 9.2 & 13.9 & 0.9 & 14.7 & 7 & 3.6 & 0.001 \\
& Above 40\% & 25.6 & 24.3 & 9.8 & 20.6 & 31.8 & 6.8 & 46.3 & 20 & 4.3 & \\
& $0-20 \%$ & 13.3 & 14 & 5.0 & 11.5 & 15 & 5 & 21 & 7 & 3.7 & \\
PSF & $20-40 \%$ & 17.9 & 14 & 13.7 & 11.5 & 16.5 & 7 & 48 & 7 & 10.2 & 0.003 \\
& Above 40\% & 38.7 & 33 & 21.0 & 23.5 & 52 & 12 & 88 & 20 & 9.2 & \\
& $0-20 \%$ & 96.1 & 95.0 & 5.7 & 92.7 & 100.0 & 88.2 & 104.3 & 7 & 4.3 & \\
EIS & $20-40 \%$ & 121.3 & 126.5 & 12.3 & 113.4 & 129.4 & 102.0 & 134.9 & 7 & 9.1 & $<0.001$ \\
& Above 40\% & 219.2 & 214.5 & 46.8 & 182.9 & 247.2 & 156.1 & 316.4 & 20 & 20.5 & \\
& $0-20 \%$ & 7.6 & 7 & 3.0 & 6 & 7.5 & 5 & 14 & 7 & 2.3 & \\
Dictation & $20-40 \%$ & 9.1 & 8 & 3.0 & 7 & 11 & 6 & 14 & 7 & 2.2 & 0.004 \\
& Above 40\% & 5.6 & 6 & 1.8 & 4 & 7 & 3 & 8 & 20 & 0.8 & \\
\hline
\end{tabular}

Captions: LNF: letter naming fluency; ISF: Initial Sound Fluency; PSF: Phoneme Segmentation Fluency; NWF: Nonsense Words Fluency; WUF: Word Use Fluency; Q: Quartile; Min: minimum; Max: maximum; N: number; Cl: confidence interval; EIS: early identification screening; $p<0.05$; ANOVA

\section{DISCUSSION}

A reliable early identification instrument for children at risk of dyslexia can furnish phonological training as early as possible, which has proved to be effective in the prevention of reading difficulties ${ }^{11-13}$. Hence, this research aimed to investigate the effectiveness of an early identification screening to enable intervention as early as possible.

The grapheme-phoneme correspondence (assessed in LNF), the phonemic awareness (assessed in ISF and PSF), and the alphabetic knowledge (tested in NWF) have been described as necessary skills for the child to learn to read and write ${ }^{14}$. Evidence suggests that these skills are powerful longitudinal predictors of how well the children will learn to read and write. With the structural equation model, authors ${ }^{15}$ demonstrate there is a bidimensional path between the phonological awareness skills and the knowledge of the graphemephoneme correspondence that influence the reading performance.

The variability in the LNF performance of same-age children who had received similar stimulation called the attention. While a child named 70 letters in 1 minute, another named four. Such variability proved to be relevant in the final writing performance, corroborating the findings in the literature that knowing the letters has a reciprocal influence on the development of phonemic awareness ${ }^{15}$. The difference in performance between the two children can demonstrate the second child's significant disadvantage when learning to read and write.

Children in the pre-literacy phase need to name letters easily and fluently so they can be successful in learning to read ${ }^{16}$. In the present study, the children whose performance was below $40 \%$ in the early identification screening were the same that identified the sound or name of the letters slowly, with effort, hesitating, and making mistakes. One year later, they also made the most mistakes in the dictation applied by the teachers. The most often mistakes were omitting or adding letters ${ }^{17}$ (vento/vto; vento/veinto); mistakes in the codification of voiceless or voiced phonemes, substituted for their equivalent ones ${ }^{17}$ (figo/fico); and those of multiple representations ${ }^{17}$ (eixo/eicho; palco/ pauco). 
Considering that learning to write in the alphabetic system implies an association between graphemes and phonemes, it is necessary to have the ability to identify and isolate the phonemes to represent them as letters ${ }^{18}$; this ability was also verified in the ISF task. As in the other tasks, there was great variability between the student with the highest score (46 points) and the one with the lowest score (0.94 points) - which means that both have quite disparate phonological skills, whereas they must meet the same academic demands.

Likewise, there was a great performance variability in the PSF skill between the child with the most segmented phonemes when the nonsense words were presented (88 phonemes) and the child with the least phonemes identified (five phonemes). Research results point out that the capacity to segment a spoken word in its constituent phonemes is essential to learn alphabetic writing ${ }^{18}$. Hence, it can be inferred how impacting the difference in performance in this skill can be when learning to read and write.

Concerning the WUF task, all the children had a similar performance. The literature has pointed out that the concept of words is difficult for children in the literacy process to understand ${ }^{19}$. However, it is suggested that phrase construction skills based on a word given be monitored and stimulated in the school setting, because the children with language development difficulties are at risk of reading comprehension difficulties ${ }^{20}$.

The findings of the present study reveal that the children that had the worst performance in the tested skills also made more writing mistakes than their peers 7 months later. This indicates that being slower to understand the alphabetic principle in the second grade could have been predicted in the first grade. This finding is coherent with information consistently reported in other studies in that children at risk of dyslexia differ from their peers in terms of phonological skills before finishing the literacy process ${ }^{21,22}$.

Functional and structural changes, such as white matter differences in the left arcuate fasciculus connecting temporoparietal regions with premotor and inferior frontal areas, were detected in children at family risk of developing dyslexia. Such changes have been related to the onset of dyslexia; since they are developed in early childhood, they are detectable before they begin learning to read and write ${ }^{23}$. On the other hand, changes in neural pathway recruitment, identified in imaging examinations, were observed after intervention based on rapid-naming training, with improved oral language and reading fluency ${ }^{24}$. Therefore, if the structural changes prove the neurobiological origin of dyslexia, if they are already present since quite early in the affected children, and if a phonological skill training can both increase the chances of a child at risk of dyslexia learning to read and write and correct neural connections that had been affected, why wait (as it is commonly done) until the child fails at school and develops secondary emotional issues to intervene only then?

The limitation presented by the study is that it was not possible to establish a direct relationship with the consolidation of dyslexia since none of the tested children was submitted to a diagnostic investigation. Neither were the children who underwent the screening followed up after the application of the dictation in second grade to confirm a more persistent difficulty. Hence, the present study cannot state that it predicts reading difficulties, although it predicts difficulties understanding the alphabetic principle and the phoneme-grapheme relationship, evidenced with a dictation.

It is essential to carry out studies to develop early intervention programs focused on prevention. From this standpoint, the family can be a great partner. Known practices, such as family literacy with conversational readings, telling stories, and reading books, can strengthen the basic skills for a healthy academic route, since "A child's future begins being traced at home" 25 .

The results provide evidence that agrees with other studies $^{22,26}$ in that children with signs of risk of dyslexia differ from children with typical development in terms of less phonological skill and that these differences are already present at the beginning of the literacy process. This reinforces the main idea of the study, that it is not enough to identify children with difficulties. Instead, they must be identified as early as possible, in first grade, to be properly stimulated, thus avoiding or minimizing the harmful consequences of school failure.

It must be considered that this pilot study was based on the comparison of the performance of children from the same class; consequently, they were presented with the same method to learn to read and write and they belonged to the same sociocultural group. Further research must be carried out at schools with larger groups of children, different literacy methods, and different sociocultural groups to seek the confirmation of the effectiveness of the early identification screening based on DIBELS 6 th $^{9}$ to identify children at risk of dyslexia. 


\section{CONCLUSION}

Based on the data analyzed, it is concluded that children with an inferior performance in phonological and letter naming skills in the first grade made more mistakes in word dictation in the second grade. In this sense, the early identification screening proved to be effective and reliable as it identified, in some children, fragile skills necessary to the literacy process. Thus, it can be a useful instrument, not only to identify but also monitor the development of skills underlying this process.

Although it cannot be stated that every child with deficits in phonological processing skills will have dyslexia, describing and identifying the signs of risk is a way to work on the child's vulnerabilities before they become difficulties/deficits. If the risk factors for dyslexia are identified early, preventive and personalized phonological skill training can be implemented to make the literacy process easier.

\section{ACKNOWLEDGMENTS}

Gratitude is extended to the staff of the participating school, especially the first-and second-grade teachers and the school's speech-language-hearing therapist, who made the whole study possible, from introduction to follow-up and the data collection.

Our special appreciation is extended to the parents and children that cooperated with the present paper.

\section{REFERENCES}

1. Wagner RK, Zirps FA, Edwards AA, Wood SG, Joyner RE, Becker BJ et al. The prevalence of Dyslexia: a new approach to its estimation. J Learn Disabil [journal on the Internet]. 2020 [cited 2020 Dec 8]; 53(5):354-65. Available at: https://journals.sagepub. com/doi/full/10.1177/0022219420920377?casa_ token $=$ GJk5x fUIEhQAAAAA\%3AKXSrkFRbpdaxplx DvA_LBPoVX6uDGKCuUWTn3BHuexKbcvUrUbcydjtll0-a-i_gTgPZ6clxnNuDg\#

2. Lyytinen $\mathrm{H}$, Erskine $\mathrm{J}$, Hämäläinen $J$, Torppa $M$, Ronimus $M$. Dyslexia-early identification and prevention: highlights from the Jyväskylä longitudinal study of dyslexia. Curr Dev Disord Rep [journal on the Internet]. 2015 [cited 2020 Jan 12]; 2(4):330-8. Available at: https://link.springer.com/ article/10.1007/s40474-015-0067-1
3. Snowling MJ. Early identification and interventions for dyslexia: a contemporary view. J Res Spec Educ Needs [journal on the Internet]. 2013 [cited 2020 Jan 12]; 13(1):7-14. Available at: https:// onlinelibrary.wiley.com/doi/abs/10.1111/j.14713802.2012.01262.x

4. Fletcher JM, Francis DJ, Foorman BR, Schatschneider C. Early detection of dyslexia risk: Development of brief, teacher-administered screens. Learn Disabil $Q$ [journal on the Internet]. 2020 [cited 2020 Nov 3]; 0(00):1-13. Available at: https://journals.sagepub.com/ doi/abs/10.1177/0731948720931870?casa_ token = Jq4tqUDV1YAAAAAA:6LKDicLN51WviTEKSbIYb4tJ8Nt-nTw6PE-EjjKM7tjbKPOF4EIc 7nFIX2XsE8MdjwOPObKPKQ0dw

5. Hendren RL, Haft SL, Black JM, White NC, Hoeft F. Recognizing psychiatric comorbidity with reading disorders. Front Psychiatry [journal on the Internet]. 2018 [cited 2020 Dec 8]; Mar 27;9:101. Available at: https://www.frontiersin.org/articles/10.3389/ fpsyt.2018.00101/full

6. Simos PG, Fletcher JM, Bergman E, Breier JI, Foorman BR, Castillo EM et al. Dyslexia-specific brain activation profile becomes normal following successful remedial training. Neurology [journal on the Internet]. 2002 [cited 2020 Nov 3];58(8):120313. Available at: https://n.neurology.org/ content/58/8/1203.short

7. Ozernov-Palchik $\mathrm{O}$, Gaab N. Tackling the early identification of dyslexia with the help of neuroimaging. Perspect Lang Lit [journal on the Internet]. 2016 [cited 2020 Nov 3]; 42(1):11-7. Available at: https://www.gaablab.com/s/Ozernov_ Palchik_Gaab-Winter-2016-Perspecitves.pdf

8. Lombardino LJ, Gauger LM. Dyslexia: Why is this diagnosis so challenging? Perspect Lang Learn Educ [journal on the Internet]. 2014 [cited 2020 Jan 12]; 21(3):98-113. Available at: https://pubs.asha. org/doi/abs/10.1044/lle21.3.98

9. Good RH, Kaminski RA. Dynamic indicators of basic early literacy skills 6th edition (DIBELS) administration and scoring guide. 2002 [cited 2019 May 12]. Available at: https://dibels.uoregon.edu 
10. Perrachione TK, Ghosh SS, Ostrovskaya I, Gabrieli JD, Kovelman I. Phonological working memory for words and nonwords in cerebral cortex. J Speech Lang Hear Res [journal on the Internet]. 2017 [cited 2020 Nov 3];60(7):195979. Available at: https://pubs.asha.org/doi/ abs/10.1044/2017_JSLHR-L-15-0446?casa_ token $=$ h24yFM2vugMAAAAA: $x-d K B N n h h-$ gmHIS7wFpWWxNhm_h5RCKKV5OLIDV09f0_ WvEhePLFvmHIYYYJG4CCONxnSbav1LPo-NF0

11. Mayeda GB, Navatta AC, Miotto EC. Intervenção fonológica em escolares de risco para dislexia: revisão de literatura. Rev Psicopedag [journal on the Internet]. 2018 [cited 2020 Dec 8]; Aug;35(107):231-41. Available at: http:// pepsic.bvsalud.org/scielo. . php? script $=$ sci_ arttext\&pid=S0103-84862018000200010

12. da Silva GF, Godoy DM. Estudos de intervenção em consciência fonológica e dislexia: revisão sistemática da literatura. Revista de Educação PUC-Campinas. [journal on the Internet] 2020 [cited 2020 Dec 8]; 12;25:1-7. Available at: http:// periodicos.puc-campinas.edu.br/seer/index.php/ reveducacao/article/view/4921

13. Silva NS, Crenitte PA. Performance of children at risk for reading difficulties submitted to an intervention program. CoDAS [journal on the Internet] 2016 [cited 2020 Dec 8]; 28(5):517-25. Available at: https://www.scielo.br/scielo.php?script $=$ sci_ arttext\&pid=S2317-17822016000500517\&lng =en\& nrm=iso\&tlng=en

14. Oliveira AM, Germano GD, Capellini SA. Students' performance in letter identification and lexical process tests. Rev. CEFAC [journal on the Internet]. 2016 [cited 2020 Dec 8]; 18(5):1121-32. Available at: $\quad$ https://www.scielo.br/scielo.php?script $=$ sci_ arttext\&pid $=$ S1516-18462016000501121\&Ing $=$ en\& $\mathrm{nrm}=$ iso\&tlng $=$ en

15. Hulme C, Snowling MJ, Caravolas M, Carroll J. Phonological skills are (probably) one cause of success in learning to read: a comment on Castles and Coltheart. Sci Stud Read [journal on the Internet]. 2005 [cited 2020 May 28]; 9(4):35165. Available at: https://www.tandfonline.com/doi/ abs $/ 10.1207 / s 1532799 \times s s r 0904$ 2?casa_token= j4xWJQrXC14AAAAA:8bHumvWHJ--Hg7P3S7p_ zzNHYuWg ILLRKblcL4K CICo1CISkMlyoQqRk1ZI bTSYdQpuMXxhOIJZFUW8
16. Alonzo CN, Mcllraith AL, Catts HW, Hogan TP. Predicting Dyslexia in children with Developmental Language Disorder. J Speech Lang Hear Res [journal on the Internet]. 2020 [cited 2020 Nov 3]; Jan 22;63(1):151-62. Available at: https:// pubs.asha.org/doi/full/10.1044/2019_JSLHR-L-180265? casa_token =eCfM2e9MOjwAAAAA\%3Aytk58 gvjoLKOK-NdH-RihYN8P4mYQGArpQ83DiyCzDww leDHFwVW5EE6XC1vdmGaW9RE4ubyfk20P-7n

17. Avila CRB, Kida ASB, Carvalho CAF de, Paolucci JF. Tipologia de erros de leitura de escolares brasileiros considerados bons leitores. PróFono R Atual Cient [journal on the Internet]. 2009 [cited 2020 May 28]; 21(4):320-5. Available at: https://www.scielo.br/scielo.php?pid=S010456872009000400010\&script $=$ sci_arttext

18. Santos MJD, Barrera SD. Impacto do treino em habilidades de consciência fonológica na escrita de pré-escolares. Psicol Esc Educ [journal on the Internet]. 2017 [cited 2020 May 28]; 21(1):93-102. Available at: https://www.scielo. br/scielo.php?script $=$ sci_arttext \&pid $=$ S1413$85572017000100093 \&$ Ing $=$ en\&nrm $=$ iso\&tlng $=p t$

19. Barrera SD, Maluf MR. Consciência metalinguística e alfabetização: um estudo com crianças da primeira série do ensino fundamental. Psicol Reflex Crit [journal on the Internet]. 2003 [cited 2020 May 28]; 6(3):491-502. Available at: https://www.scielo. $\mathrm{br} / \mathrm{scielo}$. php? script $=$ sci_arttext\&pid $=$ S0102$79722003000300008 \&$ Ing $=$ en\& $n r m=i s o \& t$ lng $=p t$

20. Corso HV. Dificuldades de aprendizagem e atrasos maturativos - atenção aos aspectos neuropsicomotores na avaliação e terapia psicopedagógicas. Rev Psicopedagogia [journal on the Internet]. 2007 [cited 2020 May 28]; 24(73):7689. Available at: http://www.revistapsicopedagogia. com.br/detalhes/370/dificuldades-deaprendizagem-e-atrasos-maturativos---atencaoaos-aspectos-neuropsicomotores-na-avaliacao-eterapia-psicopedagogicas

21. Verhoeven L, Keuning $J$. The nature of developmental dyslexia in a transparent orthography. Sci Stud Read [journal on the Internet]. 2018 [cited 2020 Dec 8]; 2;22(1):7-23. Available at: https://www.tandfonline.com/doi/ful I/10.1080/10888438.2017.1317780 
22. da Silva PB, Engel de Abreu PM, Laurence PG, Nico MÂ, Simi LG, Tomás RC et al. Rapid automatized naming and explicit phonological processing in children with Developmental Dyslexia: a study with Portuguese-Speaking children in Brazil. Front Psychol [journal on the Internet]. 2020 [cited 2020 Dec 8]; 27;11:928. Available at: https://www. frontiersin.org/articles/10.3389/fpsyg.2020.00928/ full? \&utm_source=Email_to_authors_\&utm_ medium $=$ Email \&utm_content $=T 1 \_11.5 \mathrm{e} 1$ _ a uthor \&utm _ campaign=Email_ publication\&field $=\&$ journalName $=$ Frontiers_in Psychology\&id $=520292$

23. Kuhl U, Neef NE, Kraft I, Schaadt G, Dörr L, Brauer $J$ et al. The emergence of dyslexia in the developing brain. Neurolmage [journal on the Internet]. 2020 [cited 2020 May 28]; 211:116633. Available at: https://www.sciencedirect.com/science/article/pii/ S1053811920301208

24. Vander Stappen C, Dricot L, Van Reybroeck M. RAN training in Dyslexia: behavioral and brain correlates. Neuropsychologia [journal on the Internet]. 2020 [cited 2020 Nov 3] 1;146:107566. Available at: https://www.sciencedirect.com/science/article/pii/ S0028393220302396? casa_token =sbPRdU2tB_ IAAAAA:I9MZoSO5dDtscAoEc-omWyH96yGFnel8L CIUCtMD1cH3cJylJYpWhlqZcCNLepi2Jqd1 sexjAZ ro

25. Brasil. Ministério da Educação. Secretaria de Alfabetização. Conta pra Mim: Guia de Literacia Familiar. - Brasília: MEC, SEALF, 2019. [cited 2020 Nov 7]. Available at: http://alfabetizacao.mec.gov. br/images/conta-pra-mim/conta-pra-mim-literacia. pdf

26. da Silva C, Aparecida Capellini S. Comparison of performance in metalinguistic tasks among students with and without risk of dyslexia. J Hum Growth Dev. [journal on the Internet] 2017 [cited 2020 Dec 8] 1; 27(2): 198-205. Available at: http:// pepsic.bvsalud.org/pdf/rbcdh/v27n2/10.pdf 